\title{
NOTES ON PAPUAN BIRDS.
}

By the Hon. WALter Rothschild, Ph.D., and ERnst har'Tert, Ph.D.

(Contimued from Volume X. 1903. p. 480.)

[For the localities mentioned in these notes see the "Introduction" to this series of articles in Nov. Zool. 1901. pp. 55-61, and the maps, Pls. II. and III. in the same volume of this Journal. The former portions of this series are as follows: Vol. viii. pp. 55 -88 (Introduction, Pittidae, Psittaci), and pp. 102-162 (Columbae, Megapodiidae, Rallidae, Limicolae, Alcedinidae); Vol. x. pp. 65-116 (Paradiseidae, Corvidae, Laniidae, Dicruridae, Oriolidae, Artamidae, Sturnidae), pp. 196-231 (Meropidae, Coraciidae, Podargidae, Caprimulgidae, Cypselidae, Cumpephagidae, Nectarinizdue, Dicaeidae, the genus Myzomela, Motacillidae, Sylviidae, Timeliidae); and pp. 435-480 (Meliphagidae, the genus Zosterops, Hirundinidae, Muscicapidae, additions to Dicaeidae, Laniidae, and Timeliidae). We hope to continue the subject shortly.]

\section{CUCULIDAE.}

\section{Cuculus saturatus Blyth.}

Cucưlus saturatus Blyth, Journ. As. Soc. Bengal xii. p. 942 (1843 : ex Hodgson, MS. ; Nepal).

$\delta$ fere ad., Pigén in the St. David's or Mapia group, north of Arfak, October 1896. W. Doherty coll.

$2 \uparrow q$ juv., Punatch or Bras, in the St. David's or Mapia group, October 1896. W. Doherty coll.

ठ ad., Mysol, 16. i. 1900. H. Kühn coll. (No. 17\%6.)

2 ठठ ठे fere ad., 1 q ad., Milne Bay 12. xii. 1898, 17. i. 1899. A. S. Meek coll. (Nos. 2168, 2174, 2181.)

1 o ad., Avera, Aroa River, 9. iii. 1903. A. S. Meek coll. (No. A. 386.)

\section{The Genus CACOMAntis.}

The species of the genus Cacomantis are not too well known and their nomenclature has so often been changed that it is not easy to name a Cacomantis The Papuan forms were well explained by Salvadori in the immortal Ornitologia della Papuasia, far less clearly in vol. xix. of the Cat. B. Brit. Mus. Their nomenclature has afterwards been involved, because partially wrongly interpreted by Finsch in Notes Leyden Museum xxii. pp. 81-89, thongh some valuable notes on types and others were added.

The species inhabiting New Gninea-as far as they are known to usmay be distinguished as follows :

Upper surface deep bluish schistaceons, underside bright chestnut-rufous. Wing about $115-120 \mathrm{~mm}$. Young unbarred above and below : C. castaneiventris.

Upper surface blnish schistaceous, underside dirty clouded chestnut-brown Wing about 137-142 mm. Yonng unbarred above, barred below : C. excitus.

Upper surface pale greyish olivaceous,* underside pale grey, washed with

* There appears to be a clerical error in Cat. B. Brit.Mus. xix. p. 272, where the head is said to have barely a trace of grey, while, as a rule, it is almost entirely grey with only a tinge of olivaceous. 
buffy cinnamon, under tail-coverts cinnamon buff. Young barred above and below : $C$. variolosus.

Upper surface olive-brown with a bronzy gloss; underside rufous-cinnamon, more or less washed with grey or almost entirely grey, under tail-coverts bright rufous cinnamon. Young barred above and below : $C$. assimilis.

\section{Cacomantis assimilis assimilis (Gray).}

(In onr former writings we accepted [Nov. Zool. 1901. p. 185; 1903. p. 5] for this cuckoo the name insperatus of Gould. That bird, however, is described as blue-grey above, and it came from Australia, where the present form has not been found. Dr. Finsch nsed the name dumetorum of Gould, but the same objections as to insperatus are to be made to the term dumetorum : it is described as blue-grey above, and occurs in New South Wales. Neither of the two names can therefore be accepted for a bird which is above olive-brown with a bronzy gloss which does not come from New Sonth Wales. The nomenclatures of Shelley and Finsch are thus erroneous, and we must follow Salvadori, who accepted the next early name-assimilis of Gray.)

Cuculus assimilis Gray, P.Z.S. 1858. pp. 184, 195 (Aru Islands).

Cacomantis infaustus Cabanis and Heine, Mus. Hein. iv. p. 23 (1862 : Mysol. Finsch [Notes Leyden Museum xxii. p. 81] accepts the name infaustus for the bird correctly to be called castaneiventris ; the description, however, does not fit castaneiventris, but an immature assimilis).

We have the following specimens belonging to $C$. assimilis:

3 immature birds from Dobbo and Kabroor, Aru Islands, collected by H. Kühn. 6 adult and 4 young birds from the Key Islands, collected by H. Kühn. These were formerly mentioned under the name of C. insperatus (Nov. Zool. 1903. p. 239).

1 o ad., Kisoei, 3 fairly adult ơ $q$ Teoor, 2 ad. 1 juv. Gorom, also enumerated as $C$. insperatus, l.c.

2 ơ ad., 1 med., 3 juv., Mysol, January 1900 (Nos. 1771, 1773, 1775, 1873, 1979, 1980). Collected by H. Kühn.

1 ad., 2 juv., Obi Major, collected by Lucas (No. 4) and Waterstradt.

4 ad., 5 med., 3 juv., Batjan, Doherty and Waterstradt coll.

$1 \delta$ ad., 1 q juv., Kapaur, Dutch New Guinea, December 1896, W. Doherty coll. "Iris purplish brown, darker inwardly. Feet orange, claws black. Bill black, gape and base of lower mandible reddish."

3 o ad., 1 q juv., Mafor, May and June 1897. W. Doherty coll.

1 ơ ad., Simbang, Kaiser Wilhelm's Land, 18. viii. 99. Dr. Nyman coll.

$2 \delta$ ad., 2 \% juv., Avera, Aroa River, January to March 1903. A. S. Meek coll. (Nos. A 11, 252, 432, 458.)

1 o ad., Bihagi, head of Mambare River, north side of Owen Stanley Mountains, January 1896. (No. A 231\%.) A. S. Meek coll.

1 ad., 1 med., 1 very young, Milne Bay, east coast of British New Gninea, December 1898, April 1897. (Nos. 2176, 2479, 2482.) A. S. Meek coll.

1 o ad., Collingwood Bay, June 1899. (No. 2557.) A. S. Meek coll.

\section{Cacomantis assimilis websteri Hart.}

Cacomantis websteri Hartert, in Webster's Through New Guinea p. 370, and Ibis 1899. p. 278 (New Hanover).

Besides the type specimen we have now two more, which were preserved in spirits, and both are also slaty grey on the under surface, with hardly a suspicion 
of a rufous tinge. One has the under tail-coverts grey with rufous tips and bars, the other rufous but grey towards the base.

This seems to be a fairly distinct subspecies of assimilis. In our large series of assimilis, as enumerated above, there are only two or three specimens which are uniformly grey underneath, and in those the grey is paler than in the websteri. Moreover, the under tail-coverts in the former are brighter and always rufous. It would be a very strange thing if all three adnlt New Hanover specimens were aberrations! Moreover, the young specimen from New Hanover is darker than any of our young $C$. a. assimilis.

So far we are quite at ease; but there are also Cacomantis of this group on New Ireland, New Britain, and on the d'Entrecasteanx Islands. About these we are not at all certain. Years ago we have discussed the specimens from Fergusson Islands, and we still find that they have longer bills than nearly all assimilis from other places. The few skins before us from New Ireland (three adult ones) are grey underneath, almost withont a rufous wash, and their tails are very long. This has already been pointed out by Finsch. Their under tail-coverts are uniform cinnamon rufons. One from Duke of York Island (coll. by Kleinschmidt) is more rufons nnderneath. Few of the tails are complete, and we consider this material too meagre to deduct any conclusions from. The questions are :

1. Are the birds from New Ireland, Duke of York, and New Britain the same as $C$. a. websteri?

2. Are they a closely allied form, different from websteri, and still more so from C. a. assimilis?

3. Is the form from the d'Entrecasteaux Islands another new subspecies, standing somewhat between websteri and assimilis, differing from the former by its larger bill and mostly more rufous nndersurface, from the latter by its larger bill ?

We are inclined to think that the Fergusson form requires a name, and that the one from New Ireland, etc., may perhaps be united with websteri.

\section{Cacomantis castaneiventris Gould.}

Cacomantis castaneiventris Gould, Ann. \& Mag. Nat. Hist. (3), xx. p. 269 (1867: Cape York, Australia).

Cacomantis infaustus (non Cabanis \& Heine!) Finsch, Notes Leyden Museum, xxii. p. 81.

$1 \delta$ ad. Cooktown, May 1900. Olive coll. (No. A 75.)

1 ad. Cooktown, without date. Olive coll.

1 ad. Mountains of British New Guinea, no exact locality. E. Weiske coll.

1 ad. "Between Rivers Laroki and Vanapa," Owen Stanley Mountains. E. Weiske coll.

1 “ $q$ ” ad. Kotoi district, $4000 \mathrm{ft} .$, 13. viii. 1898. A. S. Anthony coll.

$3 \delta$ ad. Avera, Upper Aroa River, January, February 1903. (Nos. A 177, 207, 313.) A. S. Meek coll.

$1 \delta, 2 q+, 1$ unsexed, all ad., $1 \delta$ juv., Owgarra, Angabunga River, November and December 1904, Jauuary 1905. (Nos. A 1874, 1884, 1916, 197\%, 2105.) A. S. Meek coll.

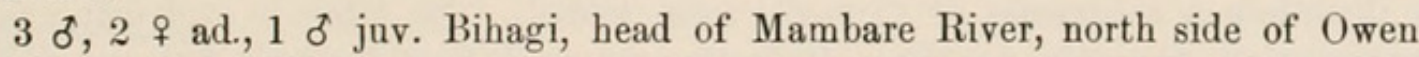
Stanley Mountains, February to April 1906. (Nos. A 2379, 2402, 2537, 2614, 2665, 2727.) A. S. Meek coll. 


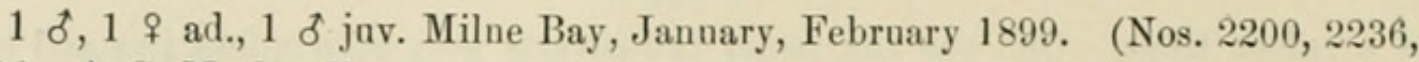
2330.) A. S. Meek coll.

Salvadori (Aggiunte Orn. Pap. I. pp. 48, 49) has separated a northern form, which, he says, is distinguished by somewhat smaller size, longer bill, and lighter under-surface, under the name of $C$. arfakianus. Its distribution is said to be the Arfak Peninsula, Salwatti, Mysol and Aru, while C. castaneiventris inhabits S.E. New Guinea and the Cape York Peninsula. Dr. Finsch says (l.c. p. 82) that he agrees with Shelley in not considering arfakianus a distinct species. As we have not seen a series of the latter, we cannot venture to decide about this, but we are a priori convinced that Salvadori is a better judge than either Shelley or Finsch, as the former had compared examples of both forms, while Shelley had before him only adult specimens of the true castaneiventris, and Finsch evidently only such of the northern form, from Arn, Mysol, Salwatti, and the Arfak Peninsula. The young bird from Key and other young ones mentioned by Finsch are evidently young assimilis.

Our series, as ennmerated above, is very constant, though there is certainly some individual variation in the brightness and intensity of the colour underneath. The young of $C$. castaneiventris differs entirely from that of $C$. assimilis. While the latter is above dark olivaceous brown with rufous crossbars and spots, and beneath also heavily barred, that of $C$. castaneiventris has the npperside chocolate brown with an olivaceons bronzy shine, without bars, the under-surface pale rusty brown, the tail dark slate with edges and bars. From this plumage they monlt straight into that of the adult bird.

We have, however, a very peculiar bird, obtained at Wanumbai, on Kobroor Island, Arn Group, 31. viii. 1900, by Heinrich Kühn. This is above like the young of . castaneiventris, but the underside is creamy white, with parts of the flanks and some few patches rufous-chestnut, as fresh feathers appear here and there. Is this the juvenile plumage of $C$. c. arfakianus? Or is there a third, hitherto unrecognised, subspecies on the Aru Islands? Only the comparison of a series of adult and young birds from Arfak as well as from the Aru Islands, with onr series from British New Guinea can decide these questions.

\section{Cacomantis excitus sp. nov.}

Supra saturate schistaceus, alis nitore aeneo-virescente, rectricibus chalybeis, albo terminatis, lateralibus albo notatis ut in formis congeneribus similibus. Mento, gula superiore, capitisque lateribus schistaceo-cinereis, collo antico, pectore, abdomine plus minusve sordide castaneo-brunneis; alarum flexuris albis, plus minusve rufescente lavatis, remigum pogoniis internis basin versus late cinerascente-albidis, ut in congeneribus; subcaudalibus saturate cinnamomeo-rufis. Al. 137-142 ; caud. 132-140; culmen 21-23 mm.

Hab. In montibus Novae Guineae meridionalis orientalis.

This most interesting new form is nearest to Cacomantis meeki from Isabel Island, Solomon Archipelago, but differs at a glance by its much smaller bill (culmen 21-23, against 26-28 in $C$. meeki), darker, more or less dirty or clouded chestnut-brown under-surface, as well as darker, more slaty chin and throat. It is doubtless a subspecies of $C$. meeki from Isabel. The latter is evidently a form representing $C$. addendus from Kulambangra and New Georgia, but we find it difficult to decide to which form of New Guinea it is nearest allied. Evidently 
C. simus and schistaceigularis of the Fiji Islands and New Hebrides are their representatives. Probably the representative on New Guinea is castaneiventris, but we prefer, in order to avoid an error, to name the new form binomially, Cacomantis excitus.

The type is No. A 2104, Owgarra, Angabunga River, 16. ii. 05. " Iris brown (light brown), feet yellow (chrome yellow, lemon yellow, dirty yellow), bill black."

We have the following skins in addition to the type :

ठ, Avera, Aroa River, 21. ii. 03. (No. A 262.) A. S. Meek coll.

$2 \delta \delta$, Bihagi, head of Mambare River, north side of Owen Stanley Mountains, 16. ii. 06. (Nos. A 2426, 2362.) A. S. Meek coll.

1 ad., Aroa River. E. Weiske coll.

The following young bird appears to belong to this form :

1 nestling, Mt. Knutsford 11,000 ft., 19. viii. 1898. A. S. Anthony coll. Upperside brown, unbarred, with rusty edges to the feathers, rectrices (quite short, not yet half-grown) bluish slate-black, the middle ones edged, the lateral ones also barred with rufous, underside barred.

\section{Cacomantis variolosus (Horsí.).}

Cuculus variolosus Vig. \& Horsf, Trans. Linn. Soc. London, xv. p. 300 (1826 : Australia). Cuculus symbonomus Müller, Verh. Nat. Gesch., Land-en Volkenk., p. 177 (1839-44: Timor).

Salvadori, Orn.-Pap. I. p. 340, and Finsch, Notes Leyden Mus. xxii. p. 89, reject the name cariolosus, probably because the type is a young bird : an arbitrary proceeding which, if followed, would-like the introduction of philological scruplesgo far to endanger stability in nomenclature.

Besides a series from Australia, the Key Islands, Ceramlaut, Batjan, Kisser and Obi, we have an adult bird shot by William Doherty near Dorey, in June 1897, and two young ones from German New Guinea, shot by Dr. Nyman and Captain Webster.

\section{Chrysococcyx meyeri Salvad.}

Chrysococcyx meyeri Salvadori, Ann. Mus. Civ. Gen., vi. p. 82 (1874: Arfak).

$1 \subsetneq$ ad., Arfak (Mori), 29. 1v. 1875. Beccari coll. (Specimen $f$ of Salvadori's list, Orn. Pap. i. p. 346.)

$1 \delta$ ad., Kapaur, 3000 ft., December 1896. W. Doherty coll.

$3 \delta$ ad., 3 ad., Bihagi, head of Mambare River, March 1906. A. S. Meek coll. (Nos. A 2515, 2552, 2599, 2611, 2612, 2653.)

1 ठ̛ ad., Aroa River, 5000 ft., January 1900. E. Weiske coll. 323.)

2 $\delta$ ad, Avera, Aroa River, 28. i., 28. ii. 03. A. S. Meek coll. (Nos. A 142,

1 \& ad., 1 ठ juv., head of Aroa River, 24, 27. iv. 05. A. S. Meek coll. (Nos. A 2115, 2130.)

$1 \delta$ ad., 1 \& ad., 1 juv. Owgarra, Angabunga River, $6000-8000$ ft., 16. xi. 04 ; 17, 10. i. 05. (Nos. A 1857, 1963, 1973.)

1 f, Kone District, British New Guinea, June 1898. A. S. Anthony coll.

$1 \delta$ ad., Mt. Cameron, Owen Stanley Range, 7000 ft., 12. viii. 1896. A. S. Anthony coll.

2 $q$ ad., Milne Bay, British New Guinea, 9. ii., 12. iv. 1899.

A. S. Meek coll. (Nos. 2286, 2460.) 
The adult male has the crown and forehead metallic green, while in the female the forehead and often the crown nearly as far as the nape, are chestunt.

The young in first plumage is very different: Upper surface yellowish brown, head and hind-neck with an ashy tinge. Quills dark brown, basal half of primaries edged and washed with chestnut rufous; bases of all the quills buff, washed with cinnamon-red. Rectrices brown with a wide blackish subterminal bar; lateral ones : onter web with two blackish and a white patch near the base, inner web with blackish base, three distinct and an indistinct blackish and three more or less sharply defined white bars on the basal half. Under-surface greyish buff, under wing-coverts cream-coloured. Bill black, base of lower mandible light, feet very light brown, iris brown.

\section{Chrysococcyx ruficollis (Salvad.).}

Lamprococcyx ruficollis Salvadori, Ann. Mus. Civ. Gen., vii. p. 913 (1875 : Hatam, Arfak).

3, Aroa River, $5000 \mathrm{ft}$., January 1900. Émil Weiske coll.

1 ठ, Owgarra, Angabunga River, $6000-8000$ ft., 14. xi. 04. A. S. Meek coll. (No. A 1847.)

$2 \delta 9$, Bibagi, head of Mambare River, north-east side of Owen Stanley Range, 16, 17. ii. 06. A. S. Meek coll. (Nos. A 2435, 2441).

"Iris reddish brown, feet greenish slate, bill blackish slate."

This series of six specimens, evidently all adult, differ from other species of Chrysococcyx by the sides of the head and neck being cinnamon rufous, the throat and jugulum more or less strongly washed with rafous-cinnamon; the throat and jugulum as well as the rest of the under-surface and under tail-coverts are barred with purplish or sometimes greenish bronze, the bars on the throat being narrower and sometimes evanescent. The upper surface is dark bronzy green, more or less washed with dark purplish bronze. Outer rectrices black, tips, four bars on onter webs and two (sometimes incomplete) bars on inner webs white, the latter partly edged with cinnamon; second pair blackish, inner webs with a round white spot at the tip and usually two rufous-cinnamon bars, central pair dark metallic green with ill-defined black base and black subapical bar.

This rare species was hitherto only known from the type from Arfak. It would, of conrse, be desirable to compare a series from the latter place with our series, but at present there is no reason to doubt their identity.

\section{Chrysococcyx poecilurus Gray.}

Chrysococcyx poecilurus Gray, P.Z.S. 1861. pp. 431, 437 ("Mysol \& New Guinea") (Type from Mysol in Brit. Museum).

1 o ad., Mysol, 13. i. 1900. Heinrich Kühn coll. (No. 1772). "Iris chocolate, eyelids carmine, feet dark plumbeous, bill black."

$1 \delta$ ad., $2 q$ ad., $1 \delta$ juv., Fergusson Island, May and June 1897. A. S. Meek coll. (Nos. 349, 391, 421, 555.)

The young is paler, less greenish above, under-surface, including the under wing-coverts, white, throat washed with dirty buff.

$1+$ ad., Sungey Bark, Kobroor, Aru Islands, 29. viii. 1900. Heinr. Kühn coll. (No. 2259).

We have also specimens from Cape York, collected by D'Albertis and Meek, and one from Atapupu, Timor, collected by Everett. 


\section{Chrysococcyx plagosus (Lath.).}

Cuculus plagosus Latham, Ind. Orn. Suppl. p. xxxi. (1801-Australia).

1 \&, Ron Island, July 1897. W. Doherty coll. "Iris reddish, feet iron-grey, bill black."

1 \& , St. Aignan, Lonisiade Islands, 28. viii. 1897. A. S. Meek coll. (No. 910.)

5 ठิ ठ, 1 \&, Woodlark Island, April 1897. A. S. Meek coll. (Nos. 188, 193, $214,216,217,21$ A. $_{\text {. }}$ Nearly all these specimens have the head and neck above metallic green, but they appear to be more or less immature, and therefore we have no donbt that they belong to $C$. plagosus.

1 juv., Owen Stanley Mountains, 11,000 ft., 23. viii. 1895. A. S. Anthony coll. This bird we believe to belong to $C h$. plagosus, though we are not certain about this. It is above dark metallic green, underneath greyish, the feathers of the throat and jugulnm with ante-apical white bars, the sides of the breast and abdomen and the under tail-coverts distinctly barred with bronzy brown, the middle of the abdomen white. Under wing-coverts with bronzy brown bars, the usual bar across the nnderside of the wing white with a buffy tinge. The feet are orange in the skin.

1 o, Aola, Guadaleanar, 4. v. 1887. C. M. Woodford coll.

1 ס, 2 우, Guadalcanar, April, May 1901. A. S. Meek coll. (Nos. 2959, $3044,3122$.

\section{1 \& Isabel, Solomon Islands, 26. vi. 1901. A. S. Meek coll. (No. 3406.)}

All these specimens from the Solomon Islands have hardly any coppery colour on the head and mantle, but again most of them are not fully adult. We therefore (in concord with all other ornithologists) cannot separate them from C.plagosus. Larger series might, however, show that Australian specimens have longer wings than those from New Guinea and the Papuan Islands.

In Nov. Zool. 1905. p. 258 we recorded a male of C. plagosus from Bongainville, but this specimen is a $C$. lucidus, an error which we herewith correct.

\section{Calliechthrus leucolophus (Müll.).}

Cuculus leucolophus S. Müller, Verh. Nat. Gesch. Ned. Ind., "Land- en Volkenkunde,” p. 22 (1844Lobo Bay).

Known from New Guinea, Salwatti, Waigin and Mysol. We have the following specimens :

2 without labels, Dntch New Guinea. (Preparation of Bruijn's hunters.)

$1 \delta$, North coast of Dutch New Guinea, between $136^{\circ}$ and $137^{\circ}$ long. (Bruijn's hunters.)

2 ठठ ठ, Kapaur, December 1896, February 1897. William Doherty coll.

1 jun., Constantinhafen, Kaiser Wilhelm's Land. Kubary coll.

3 ơ 9 , Milne Bay, 18, 26. iii., 9. iv. 1899. A. S. Meek coll. (Nos. 2383, 2479, 2450.)

1 ad., 1 immat., Mountains of British New Guinea. (Purchased.)

1 immat., Brown River, British New Gninea. E. Weiske coll.

2 immat., Mount Cameron, Owen Stanley Mountains, August 1896. A. S. Anthony coll.

4 ơ ठ, 1 \&, Avera, Aroa River, January, February, March 1903. A. S. Meek coll. (Nos. A 83, 123, 274, 381, 431.)
1 ठ, Owgarra, Angabunga River, 28, x. 04.
A. S. Meek coll.
(No. 180\%.) 
$2 \delta$ ठै, 1 \&, Bihagi, head of Mambare River, February, March 1906. A. S. Meek coll. (Nos. A 2443, 2597, 2657.)

1 ad., Sattelberg, German New Guinea, January 1905. C. Wahnes coll.

\section{Eudynamis orientalis cyanocephalus (Lath.).}

(For a review of the genus see Hartert, Nov. Zool. 1903. pp. 235-238.)

Cf. Nov. Zool. 1903. p. 237.

1 \& ad., "Popo inland, W. district," 5. vi. 1896. A. S. Anthony coll.

$1 \delta$ ad., Monnt Cameron, Owen Stanley Mountains, 19. viii. 1896. A. S. Anthony coll.

We must, from its size (wing $206 \mathrm{~mm}$.), regard the male specimen as a cyanocephalus. The female is quite typical, and proves the occurrence of this form in S.E. New Guinea.

\section{Eudynamis orientalis rufiventer (Less.).}

Cf. Nov, Zool. 1903. p. 238.

$1 \delta$ ad., 1 o juv. Arfak preparation. No exact locality.

2 ठैठ 1 , 1 , "Talandjang " (?), Dutch New Gninea. (Ex Bruijn.)

$2 \uparrow q$, Taraway, May 1884. (Ex Bruijn.)

of $\&$ ad., Ron Island, Jnly 1897. W. Doherty coll.

$1 \delta$ ad., "Southern New Guinea "? D'Albertis coll., original label lost.

$1 \delta$ ad., Yule Island, November 1875. D'Albertis and Tomasinelli coll. (Wing $195 \mathrm{~mm}$.)

\section{Eudynamis orientalis alberti subsp. nov.}

Eudynamis orientalis subsp. nov.? Rothschild \& Hartert, Nov. Zool. 1905. p. 257.

$1 \delta$ ad., Gizo, Solomon Islands, 31. x.03. A. S. Meek coll. (No. A 696.)

$2 \delta$ ad., Choiseul, Solomon Islands, December 1903. A. S. Meek coll. (Nos. A 886, 1041.)

Besides being smaller (wings $180-185 \mathrm{~mm}$.), the upperside, especially the head and mantle, are deeper and more of a bluish black, and we therefore no longer refrain from naming this form.

Type: $\delta$ ad., Gizo, 31. x. 03. (No. A 696.)

We hope to see the females of this form before long.

Named in honour of Mr. Albert Meek.

\section{Eudynamis orientalis salvadorii Hart.}

Cf. Nov. Zool. 1900. p. 232 ; 1903. p. 238.

$\delta$ ad., New Ireland. Collected by a missionary. Type of E. o. salvadorii.

$\delta$ ad., New Britain. Bought from the "Linnaea" in Berlin.

i ad., New Ireland. Collected by a missionary.

$q$ ad., New Britain. Kleinschmidt coll. (Ex Mus. Godeffroy.) (No. 15553.)

\section{Microdynamis parva (Salvad.).}

Eudynamis parva Salvadori, Ann. Mus. Civ. Gen, vii. p. 986 (1875-? Tidori, Beccari coll.).

ठ ad. Ron Island, July 1897. W. Doherty coll. "Iris searlet, feet slaty-grey, bill black." 
1 juv., Mount Maori, near Humboldt Bay, Jannary 1899. J. M. Dumas coll.

1 juv., near Humboldt Bay. J. Dumas coll.

1 ( $q$ ?), Sattelberg, German New Gninea, December 1905. C. Wahnes coll.

1 ơ, 2 $q$, Milne Bay, 30. i., 14. ii., 18. iv. 1899. A. S. Meek coll. (Nos. 2213, 2316, 2478.)

$1 \delta$ ad., Kone district, British New Gninea, June 1898. A. S. Anthony coll.

1 o ad., Oriori district, British New Guinea, 20. i. 1896. A. S. Anthony coll.

1 juv., Kotoi district, British New Guinea, August 1898. A. S. Anthony coll.

$1 \delta, 2 q q$ or juv., Owen Stanley Mountains. Emil Weiske coll.

It is possible that there is a northern, darker, and a sonthern, lighter and more rufescent form of $M$. parva, but the present material is not sufficient to decide this question, as there is great variation between the specimens from one place. It is certain that the adult male has the crown and monstachial stripe glossy blneblack, and that it moults into this plumage from a barred juvenile dress without black crown or monstachial stripe. The adult female has been described as having a broad greenish black collar at the back of the neck, but probably this is wrong, and the female has no black collar, the birds with the latter being juvenile males in moult. The evidently young birds as well as the old ones differ strikingly in the shades of colour. A larger series, with trustworthy sex-notes and dates, from different places, is desired to clear up the questions raised above.

\section{Scythrops novaehollandiae Lath.}

Scythrops novaehollandiae Latham, Ind. Orn. i. p. 141 (1790-Australia).

1 ad., Arfak (?), native skin.

1 i ad., Duke of York Island, June 1880. Th. Kleinschmidt coll. (No. 4679.) Ex Mus. Godeffroy.

$\delta$ \& , Trobriand Islands, 12, 15. iv. 1895. A. S. Meek coll.

2 Nicura, British New Guinea, August 1893. Lix coll.

1 б, Yule Island, 3. vi. 1875. D'Albertis coll. (No. 192.) Specimen $f$ of Salvadori's list in Orn. Pap. i. p. 374.

\section{Centropus menbeki menbeki Less. \& Garn.}

Centropus menbeki (sic) Lesson \& Garnier, Voy. Coquille, Zool. Atlas pl. 33 (1826-N.W. New Guinea).

ठ ad., Mysol, 1. xii. 1883. Guillemard coll.

2 ठ์ ठै, 1 q, Mysol, Jannary 1900. Heinr. Kühn coll. (Nos. 1871, 1872, 2059.)

$1 \delta$ ad., 2 not sexed, Andai, Arfak. Bruijn coll.

1 ad., Hatam, Arfak, February 1877. Ex Bruijn.

1 \&, Arfak. Bruijn coll.

$1 \delta$, Arfak. Bruijn coll. Specimen $g$ of Salvadori's list, Orn. Pap. i. p. 378.

ơ + , Dorei, Arfak, June 1897, October 1896. W. Doherty coll.

$2 \delta \delta, 1$ (?), Takar, October and November 1896. W. Doherty coll.

1 ठ̊, Kapaur, November 1896. W. Doherty coll.

$1 \delta$, Awek, Jobi Island, April 1875. Ex Bruijn. Specimen $q$ of Salvadori's list, t.c. p. 378 .

$\delta$ juv., $q$ ad., Surui, Jobi Island, January 1883. Ex Bruijn.

1 juv., Kaririri, Jobi Island. Bought from native by W. Doherty.

1 ad., Triton Bay, 25. vii. 1896. Capt. Webster coll. (No. 291.) 
1 ơ, Sattelberg, 20. vii. 1897. E. Nyman coll.

1 f, Fly River, 31. v. 1877. D'Albertis coll. (No. 34). No. $n^{3}$ of Salvadori's list, l.c.

1 ठ, Mailu, British New Guinea, 5. viii. 1895. A. S. Anthony coll.

$1 \delta, 1$ (?), Mount Cameron, Stanley River, 2000 ft., 20. ix. 1896. A. S. Anthony coll.

The amount of greenish gloss varies. Some examples, especially those from the Fly River and Jobi, show a lot of bluish, almost purplish gloss, thus approaching the Aru form. The specimens collected by Anthony have very huge bills. A better series from the Mountains of British New Guinea should be compared to show if there is any constant difference.

\section{Centropus menbeki aruensis Salvad.}

Centropus aruensis Salvadori, Ann. Mus. Civ. Gen. xii. p. 317 (1878-Aru Islands).

$\delta$ ad., Soengej Wanumbai, Kobroor Island, Aru Islands, 3. ix. 1900. Hch. Kühn coll. (No. 443.)

This specimen is very typical, showing a strong, almost purplish blue gloss on the entire upper surface and tail.

$1 \delta$ ad., Trangan, Aru Islands, 20. ix. 1900. Heh. Kühn coll. (No. 2448.)

This example is not so typical, showing very little of a blue sheen, thus being similar to some specimens of $C . m$. menbeki. There is no other difference than the blue gloss, and single specimens are sometimes not separable, therefore $C$. menbeki menbeki and $C$. menbeki aruensis are orly subspecies.

\section{Centropus violaceus Qnoy \& Gaim.}

Centropus violaceus Quoy \& Gaimard, Voy. Astrolabe, Zool. i. p. 299 (1830-New Ireland).

$1 \delta$ ad., New Ireland. Collected by a missionary.

Differs from $C$. menbeki in the uniform purple or violet-blne colonr, perfectly black bill, bnt light (reddish) bare skin round eyes and yellow feet. Probably subspecies of menbeki.

\section{Centropus chalybeus (Salvad.).}

Nesocentor chalybeus Salvadori, Ann. Mus. Civ. Gen. vii. p. 915 (1875-Misori).

$2 \uparrow q$, Korrido, 1879 (Misori). Ex Bruijn coll.

Differs from $C$. menbeki and agrees with violaceus in having a quite black bill. The bare facial skin and feet are dark, the gloss dark steel-blue. Probably subspecies of menbeki and the rest. About the names Korrido (Kordo) and Misori see Nov. Zool. 1901. p. 58.

\section{Centropus nigricans (Salvad.).}

Polophilus nigricans Salvadori, Ann. Mus. Civ. Gen. ix. p. 17 (1876-Naiabui and Yule Island).

$\delta$ fere ad., Naiabui, British New Guinea, October 1875. D'Albertis coll. Specimen $c$ of Salvadori's list, Orn. Pap. i. p. 390.

3 jun., Nicura, British New Guinea. Lix coll.

$1 \delta$ ad., Fergusson Island, D'Entrecasteaux group, 12. x. 1894. A. S. Meek coll. 


\section{Centropus ateralbus Less.}

Centropus ateralbus Lesson, Férussac's Bull. Sc. Nat. viii. p. 113 (1826-New Ireland).

2 ad., 2 semi-ad., New Ireland. Collected by a missionary.

\& ad. New Britain, 3. vii. 1886. Kubary coll.

ठ juv., New Britain, 25. v. 1886. Kubary coll. Native name : "A kamúk."

2 ơ $\delta$ ad., Blanche Bay, New Britain. Otto Finsch coll.

\section{Centropus bernsteini Schleg.}

Centropus bernsteini Schlegel, Ned. Tijdschr. v. Dierk. iii. p. 251 (1866-(?) Salwatt1,

1 ad., Sattelberg, German New Guinea. C. Wahnes coll.

$1 \delta$ juv., Stephansort, German New Guinea, December 1899. G. Nyman coll.

\section{STRIGES.}

\section{Ninox theomacha (Bp.).}

Spiloglaux theomacha Bonaparte, Compt. Rend. xli. p. 654 (1855-Triton Bay).

1 , Arfak (one of Bruijn's skins).

1, Ambernoh River. J. Dumas coll.

1 f, "North coast British New Guinea," 8. xi. 03. H. G. Liverey coll.

$1 \delta$, Aroa River, $5000 \mathrm{ft}$. E. Weiske coll. coll.

$2 f q$, Avera, Aroa River, February 1903. (Nos. A 191, 285.) A. S. Meek

4 ठิ ठे, 1 ๆ, Owgarra, Angabunga River, October, November 1904, January 1905. (Nos. A 1805, 1806, 1819, 1825, 1951.) A. S. Meek coll. " Iris orangeyellow, feet lemon-yellow, bill slate, darker at base."

1 o, Waigin, 28. xii. 02. J. Waterstradt coll.

1 \&, Mysol, 26. i. 1900. (No. 1909.) H. Kühn coll.

It is quite possible that there are two or three subspecies united here under $N$. theomacha. The specimens from Dutch New Gninea are perhaps a little smaller, and so is certainly that from Mysol, which, moreover, is less rufons, more chocolatine, underneath. If the Mysol bird differs, its name will be $N$. $t$. hoedti Schleg. 1871.

\section{Ninox dimorpha (Salvad.).}

Athene dimorpha Salvadori, Ann. Mus. Civ. Genova vi. p. 308 (1874-Sovong).

1 ad., 1 pull., Dutch New Guinea (from dealers).

1 ad., Ambernoh River. J. Dumas coll.

1 ad., Mount Victoria, Owen Stanley Range, 5000_7000 ft., April—June 1896. Native coll.

1 ad., Babooni, British New Guinea, September 1903. A. E. Pratt coll.

1 ơ, Milne Bay, British New Guinea, 3. ii. 1899. (No. 2251.) A. S. Meek coll.

1 o , Collingwood Bay, British New Guinea, 15. vi. 1899. (No. 2613.) A. S. Meek coll. culmen,"

" Iris bright yellow, feet lemon-chrome, bill dark slate, zinc-colour along the 
Ninox variegata (Quoy \& Gaim.).

Nectua variegatu Quoy \& Gaimard, Voy. Astrol. Zool. i. p. 166. pl. i. (1833-New Ireland).

We have two specimens collected on New Hanover by Capt. Webster.

\section{Ninox goldii goldii Gurney.}

Ninox goldii Gurney, Ibis 1883. p. 169 (S.E. New Guinea. Probably this is erroneous, as in many other cases with Goldie's birds, and the types were from Fergusson Island). (Cf. Nov. Zool. 1896. p. 246.)

Ninox goodenoviensis De Vis, Report on Birds from Brit. New Guinea (Government Report) 1890.

Besides the examples from Fergusson we have now two from Goodenough, $1 \delta$ ad. 1 juv. The latter has more white on the scapulars and wing-coverts, and the inner secondaries have large round white spots on the inner webs, these spots getting larger towards the base. The under-surface is not bright rusty rufous spotted with white, as in the adult bird, but whitish with brown longitudinal spots and pale rusty tips to the feathers. Ninox goodenoviensis is undoubtedly the same as goldii.

We cannot find that the description of Ramsay's N. terricolor (Proc. Linn. Soc. N. S. Wales, iv. 1879 . p. 466) can apply to $N$. goldii. The description is very confused, but that of the tail and wings does not fit $N$. goldii, moreover the measurements are considerably smaller. We therefore think that $N$. terricolor must be a species or subspecies not yet known in Europe.

\section{Ninox rufa humeralis (Bp.).}

Athene humeralis Bonaparte, Consp. i. p. 40 (1850- "Oceania." Ex Hombr. et Jacq., Voy. Pôle Sud, Atlas. pl. iv. fig. 1. "New Guinea").

1 juv., moulting to adult plnmage, Dutch New Guinea. Ex Boucard. (No. 46.)

1 ad., Ambernoh River, Dutch New Gninea. J. Dumas coll.

1 ad., Brown River, British New Guinea. E. Weiske coll. 1898.

1 jun., Mt. Kebea, 4000 ft., June 1902. A. E. Pratt coll.

1 oे, 1 q, Milne Bay, 13, 17. ii. 1899. (Nos. 2300, 2344.) A. S. Meek coll.

1 \&, Collingwood Bay, 28. v. 1899. (No. 2530.) A. S. Meek coll.

"Iris lemon chrome, light lemon, pale yellow. Feet light lemon chrome. Bill: bluish enamel down centre on top, sides blne-slate, under-mandible bluish enamel."

The downy young is white.

\section{Ninox? ?}

A yonng owl in light cinnamon down, with wings and tail developed, which are brown with rufous bars, does not seem to belong to any owl we know of. Possibly it is the young of a hitherto unkuown species. It is from British New Guinea, and was bought from Messrs. Burns, Philp \& Co.

\section{Ninox connivens connivens (Lath.).}

Falco connirens Latham, Ind. Orn. Suppl, ii. p. 12 (1801-Australia).

This is an Australian large form with very distinct bars on the tail. We have specimens from Cairns and other places in Queensland. 


\section{Ninox connivens occidentalis Rams.}

Ninox connivens occidentalis Ramsay, Proc. Linn. Soc. N. S. Wales i. (2) p. 1086 (1886-N.W. Australia).

A more western form, smaller, with the stripes on the underside more rusty. Cf. Nov. Zool. 1905. p. 210.

Probably $N$. peninsularis Salvad. from Cape York is a closely allied form of this species.

\section{Ninox connivens assimilis (Salvad. and D'Alb.).}

Ninox assimilis Salvadori and D'Albertis, Ann. Mus. Civ. Genova vii. p. 809 (Southern New Guinea).

Very much smaller than the Australian allies, and with the bars on the tail less conspicnous, becanse they are only of a paler brown than the rest of the tail.

We have only one specimen of this owl, withont reliable locality, but doubtless from the mountains of British New Guinea, purchased from Messrs. McIlwraith \& Co., in London. Wing $260 \mathrm{~mm}$.

\section{Ninox connivens rufostrigata (Gray).}

Athene rufostrigata G. R. Gray, Proc. Zool. Soc. London 1860. p. 344. (Gilolo).

Quite like $N$. c. assimilis, with the bars to the tail equally inconspicuous, but much larger.

We have two specimens from Morty (J. Dumas coll.), wings about $285 \mathrm{~mm}$, one $\delta$ ad. from Batjan (J. Waterstradt coll.), wing about 278, a pullns from Batjan (Doherty coll.), and a bird, marked $\delta$, obtained on Obi Major by Waterstradt's hunters; this is at first glance a puzzling bird, agreeing in size with our assimilis, but the primaries are not fully grown.

\section{Strix tenebricosa arfaki Schleg.}

Strix arfaki Schlegel, Notes Leyden Museum i. p. 101 (1879-Arfak).

Mr. Meek sent a series of eight specimens from the Upper Aroa River. The males agree with other males from the mountains of British New Guinea, while the females are considerably larger. Strix arfaki is merely a darker and somewhat larger Papuan form of the North Australian Strix tenebricosa Gould.

1 \&, Avera, Aroa River, 4. vi. 03. (No. A 601.) Wing about $293 \mathrm{~mm}$.

$2 \delta$ ठै, Owgarra, Angabunga River, above 6000 ft., 9, 13. i. 05. (Nos. A 1969, 1985.) Wings about $255 \mathrm{~mm}$.

$1 \delta, 4 q q$, Head of Aroa River, 4000-6000 ft., April and May 1905. (Nos. A 2132, 2133, 2139,2161, one without number.) Wing, o $255 \mathrm{~mm}$. , $+285-305 \mathrm{~mm}$.

1 \& (? ठ !), Collingwood Bay, 8. vi. 1899. (No. 2585.) Wing $270 \mathrm{~mm}$.

"Iris black, brown, dark brown, bluish black. Feet dirty greenish slate, vandyke-brown, smoky brown. Bill blackish horn, black, slate on top, light brown underneath." 
A quite young bird, not yet fully grown (No. A 2088), has on the upperside, which is strongly mottled with black, some broader buffy white shaft-lines and is less decidedly cross-barred, the bars running together and forming irregular blackish markings. Eleven females-apparently adult, but possibly not so(Nos. A 2012, 2044, 2050, 2057, 2058, 2059, 2061, 2076, 2087, 2089, B 115) are all much more brown above. Each feather has a white or buffy white shaft-line (not merely a white shaft), the inuer web is black, sometimes quite uniform, but mostly with large rufons spots or cross-markings; sometimes both webs are black with rufous markings. The outer web, however, is generally brown with some blackish mottlings. The under-surface is always strongly marked with somewhat harpoon-shaped cross-lines, which are broader than in the males. Another specimen marked "female" (No. 105) has underneath narrow cross-lines as in the males; the npper surface is less deep and more of a rusty brown, the outer webs of the feathers uniform, some with a greyish tinge, the inner webs with large black cross-patches and rufous spots. I suspect that this specimen is really a male. A very young bird (B 3), obtained on Yule Island, 14. x. 04, has the middle of the chest and the ground-colonr of the abdomen buffy white, and may possibly not belong to $S$. plumbeus but to another species or subspecies. Count Salvadori has considered specimens from Port Moresby as belonging to S. cervinus Gould, which is said to be a northern form of S. australis, bnt its distinctness is doubtful. Mr. Meek describes the iris of the males as dark red or yellowish, that of the females as pale yellowish and dark red; bill slaty blue with black ridge, blnish slate, or slate-colour; feet greenish yellow, sage-green, or dirty yellow.

An egg from Owgarra (26. xii. 05) has a very thick shell with numerons little pits, as if from the point of a needle, and is of a greenish buff-colour, almost without gloss. It measures $32.5 \times 25 \mathrm{~mm}$.

\section{Turnix maculosus (Temm.).}

Hemipodius maculosus Temminck, Pig. et Gallin. iii. pp. 361, 757 (1815-Australia). (Cf. Nov. Zool. 1904. p. 177.)

ठㅇ, Upper Aroa River, 6. xii. 04. (Nos. B 92, 93.)

"Iris pale yellowish white. Feet sage-green. Bill: $\delta$, greenish yellow $q$, greenish yellow, brownish towards the tip."

\section{Ptilinopus superbus (Temm. \& Knip).}

Cf. Nov. Zool. 1901. p. 102.

2 ठิ ठै, Avera, Aroa River, 20. i., 16. xi. 03. (Nos. A 23, A 236.)

2 ठे ठे, Upper Aroa River, 18. i., 20. iv. 05. (Nos. B 173, 230.)

\section{Ptilinopus pulchella (Temm.).}

Cf. Nov. Zool. 1901. p. 102.

1 б, Bubuni, Aroa River, 23. iv. 05. (No. B 244.)

\section{Ptilinopus coronulatus coronulatus Gray.}

Cf. Nov. Zool. 1901. p. 102.

2 of of, Upper Aroa River, January' 1905. (Nos. B 131, 181.) 


\section{$2 \mathrm{BHL}$ Biodiversity Heritage Library}

Rothschild, Lionel Walter Rothschild and Hartert, Ernst. 1907. "Notes on Papuan birds." Novitates zoologicae : a journal of zoology in connection with the Tring Museum 14, 433-446. https://doi.org/10.5962/bhl.part.25382.

View This Item Online: https://www.biodiversitylibrary.org/item/21973

DOI: https://doi.org/10.5962/bhl.part.25382

Permalink: https://www.biodiversitylibrary.org/partpdf/25382

\section{Holding Institution}

Natural History Museum Library, London

\section{Sponsored by}

Natural History Museum Library, London

\section{Copyright \& Reuse}

Copyright Status: Public domain. The BHL considers that this work is no longer under copyright protection.

This document was created from content at the Biodiversity Heritage Library, the world's largest open access digital library for biodiversity literature and archives. Visit BHL at https://www.biodiversitylibrary.org. 